\title{
TELAAH KRITIS MENGENAI INTERPRETASI KEDARURATAN KESEHATAN MASYARAKAT SEBAGAI KEADAAN MEMAKSA BERDASARKAN PERSPEKTIF HUKUM KONTRAK
}

\author{
(Critical Appraisal of the Interpretation of Public Health Emergency as Force Majeure \\ Condition Based on the Perspective of Contract Law)
}

\author{
Kristianus Jimy Pratama \\ Fakultas Hukum Universitas Gadjah Mada \\ Jl. Sosio Yustisia Nomor 1, Bulaksumur, Kabupaten Sleman, Daerah Istimewa Yogyakarta 55281 \\ e-mail: kristianusjimy@mail.ugm.ac.id
}

\begin{abstract}
Abstrak
Pemberlakuan Keputusan Presiden Nomor 11 Tahun 2020 tentang Penetapan Kedaruratan Kesehatan Masyarakat Corona Virus Disease (Covid-19) dan Keputusan Presiden Nomor 12 Tahun 2020 tentang Penetapan Bencana Nonalam Penyebaran Corona Virus Disease (Covid-19) Sebagai Bencana Nasional berimplikasi pada terdampaknya berbagai aspek pembidangan hukum termasuk bidang hukum kontrak di dalamnya. Keadaan kedaruratan kesehatan masyarakat sebagaimana yang ditegaskan dalam norma hukum terkait membuat ruang untuk terjadinya ragam penafsiran hukum diantara para pihak dalam menerapkan klausula keadaan memaksa dalam kurun waktu keadaan kedaruratan kesehatan masyarakat tersebut terlebih setelah diberlakukannya Peraturan Pemerintah Nomor 21 Tahun 2020 tentang Pembatasan Sosial Berksala Besar Dalam Rangka Percepatan Penanganan Corona Virus Disease 2019 (Covid-19). Oleh karena itu, diperlukan penelaahan lebih lanjut mengenai batasan-batasan dalam menerapkan klausula keadaan memaksa yang dihubungkan dengan keadaan kedaruratan kesehatan masyarakat tersebut. Penelitian ini merupakan penelitian hukum normatif yang ditunjang dengan studi kepustakaan. Melalui penelitian ini kemudian dirumuskan kesimpulan yang menerangkan bahwa terdapat syarat-syarat yang harus terpenuhi secara akumulatif untuk menetapkan kedaruratan kesehatan masyarakat sebagai klausula keadaan memaksa. Selain itu juga ditegaskan di dalam penelitian ini bahwa para pihak juga dapat melakukan renegoisasi kontrak yang meliputi pilihan untuk memperbaharui atau memutus kontrak tersebut untuk mencapai kepastian hukum diantara para pihak.
\end{abstract}

Kata kunci: Hukum Kontrak, Keadaan Memaksa, Penafsiran Hukum

\begin{abstract}
The enactment of 2 related regulations as a form of response to the pandemic namely Presidential Decree No. 11 Year 2020 on Stipulation of Public Health Emergencies for Corona Virus Disease 2019 (Covid-19) and Presidential Decree No. 12 Year on The Declaration of A Non-Natural Disaster From The Spread of Corona Virus Disease 2019 As a National Disaster has implications in law field especially for contract law. This public health emergency is making the multiple interpretations among the parties to applying force majeure clauses especially after the enactment of Government Regulation No. 21 Year 2020 on LargeScale Social Limits to Accelerate the Management of Corona Virus Disease 2019 (Covid-19). This research is a legal normative research with supported by literature study. Therefore, this research has purpose to particularize the limitations of force majeure clause related to public health emergency.
\end{abstract}

Keywords: Contract Law, Force Majeure, Legal Interpretation

\section{A. Pendahuluan}

Cicero mengungkapkan keselamatan rakyat merupakan hukum tertinggi di dalam suatu negara. ${ }^{1}$ Frasa keselamatan rakyat tersebut

Pendapat ini dikenal juga dengan adagium salus populi suprema lex esto. Lihat: Marcus Tullius Cicero, De Re 
dapat ditafsirkan dengan dua metode yaitu metode segmentatif dan metode integratif. Keselamatan rakyat dalam metode segmentatif merupakan konsep yang tersegmentasi ke dalam bidang-bidang kehidupan bermasyarakat tertentu secara terpisah sedangkan keselamatan rakyat dalam metode integratif merupakan suatu konsepsi yang terdiri dari berbagai bidangbidang kehidupan bermasyarakat yang saling terikat dan bertimbal balik.

Sebagaimana yang dimaksud baik dalam metode segmentatif ataupun metode integratif, konsep keselamatan rakyat dapat terdiri dari segmen-segmen yang bersifat multidisipliner. Salah satu segmen yang dimaksudkan adalah segmen kesehatan. Mengutip ketentuan Pasal 12 ayat (1) International Covenant on Economic Social, and Cultural Rights 1996 (selanjutnya disebut dengan ICESCR) menerangkan bahwa terdapat pengakuan tegas terhadap hak semua orang untuk menikmati standar kesehatan fisik dan kesehatan mental yang paling baik. ${ }^{2}$ Secara khusus merujuk pada ketentuan Pasal 12 ayat (2) huruf (c) ICESCR dikemukakan bahwa salah satu langkah yang dapat ditempuh oleh negara pihak pada konvenan ini untuk mencapai realisasi penuh hak yang dimaksudkan pada ketentuan Pasal 12 ayat (1) ICESCR maka dapat dilakukan dengan pencegahan, pengobatan, dan pengendalian atas epidemi, endemik, penyakit yang disebabkan oleh suatu pekerjaan, dan penyakit lainnya. ${ }^{3}$

Langkah sistematik terkait kemudian direalisasikan melalui Undang-Undang Nomor 6
Tahun 2018 tentang Kekarantinaan Kesehatan (selanjutnya disebut dengan UU Kekarantinaan Kesehatan). Hal tersebut sejalan dengan ketentuan Pasal $28 \mathrm{H}$ ayat (1) Undang-Undang Dasar Negara Republik Indonesia Tahun 1945 (selanjutnya disebut dengan UUD NRI Tahun 1945) yang menjelaskan bahwa setiap orang berhak hidup sejahtera lahir dan batin, bertempat tinggal, dan mendapatkan lingkungan hidup yang baik dan sehat serta berhak memperoleh pelayanan kesehatan. ${ }^{4}$ Namun dewasa ini efektifitas dari pemberlakuan UU Kekarantinaan Kesehatan tersebut berada pada titik uji. Hal ini dikarenakan timbulnya permasalahan yang dihadapi oleh masyarakat di Indonesia akibat terjadinya pandemi Coronavirus Disease 2019 (selanjutnya disebut dengan Covid-19). Sebagaimana yang diterangkan dalam metode integratif sebelumnya, segmen kesehatan tidak dapat berdiri tanpa melakukan timbal balik dengan segmen lain dalam konsep keselamatan rakyat yaitu di antaranya adalah segmen ekonomi dan segmen sosial kemasyarakatan. Seiring dengan pernyataan tersebut, pandemi Covid-19 di Indonesia telah berdampak secara luas tidak hanya pada segmen kesehatan tetapi juga bersifat menyeluruh pada segmen-segmen lain seperti segmen ekonomi dan segmen sosial kemasyarakatan.

Hal tersebut dipertegas dengan diberlakukannya tiga norma hukum yang meliputi Peraturan Pemerintah Nomor 21 Tahun 2020 tentang Pembatasan Sosial Berskala Besar Dalam Rangka Percepatan Penanganan Corona

Publica, De Legibus, Cato Maior de Senectute, Laelius de Amicitia, (Oxford: Oxford University Press, 2006), hlm. 204. Lihat juga: Phoebe E. Arde-Acquah, "Salus Populi Suprema Lex Esto: Balancing Civil Liberties and Public Health Interventions in Modern Vaccination Policy, Washington University Jurisprudence Review, Vol.7 No.2, Washington University School of Law, 2015, hlm. 337.

2 Pasal 12 ayat (1) International Covenant on Economic Social, and Cultural Rights 1996.

Pasal 12 ayat (2) huruf (c) jo. Pasal 12 ayat (1) International Covenant on Economic Social, and Cultural Rights 1996.

Pasal 28H ayat (1) Undang-Undang Dasar Negara Republik Indonesia Tahun 1945. 
Virus Disease 2019 (Covid-19) (selanjutnya disebut dengan PP 21/2020), Keputusan Presiden Nomor 11 Tahun 2020 tentang Penetapan Kedaruratan Kesehatan Masyarakat Corona Virus Disease (Covid-19) (selanjutnya Keppres 11/2020) dan Keputusan Presiden Nomor 12 Tahun 2020 tentang Penetapan Bencana Nonalam Penyebaran Corona Virus Disease (Covid-19) Sebagai Bencana Nasional (selanjutnya disebut dengan Keppres 12/2020). ${ }^{5}$ Berdasarkan norma hukum tersebut secara eksplisit, hak atas kesehatan dalam menghadapi pandemi Covid-19 merupakan tanggung jawab negara karena memuat aturan yang bersifat publik meskipun hak atas kesehatan menjadi hak asasi yang melekat pada setiap individu. Sehingga dapat dinyatakan bahwa ketiga norma hukum yang menjadi respon atas terjadinya pandemi Covid-19 di Indonesia merupakan hukum publik. $^{6}$

Mengacu pada PP 21/2020, Keppres $11 / 2020$, dan Keppres 12/2020 pada prinsipnya membahas mengenai hal yang sama yaitu kedaruratan kesehatan masyarakat. Secara yuridis, kedaruratan kesehatan masyarakat merupakan kejadian kesehatan masyarakat yang bersifat luar biasa dengan ditandai penyebaran penyakit menular dan/atau kejadian yang disebabkan oleh radiasi nuklir, pencemaran biologi, kontaminasi kimia, bioterorisme, dan pangan yang menimbulkan bahaya kesehatan dan berpotensi menyebar lintas wilayah atau lintas negara.' PP 21/2020, Keppres 11/2020, dan Keppres 12/2020 tersebut mempunyai daya berlaku mengikat secara umum sehingga ketiga norma hukum memberikan konsekuensi logis termasuk dalam bidang hukum kontrak.

Permasalahan hukum yang kemudian timbul adalah terkait karakteristik dari keadaan kedaruratan kesehatan masyarakat dan klausul keadaan memaksa yang terdapat dalam sebuah kontrak. Terlebih apabila berkenaan apabila para pihak telah memasuki fase post-contractual sebelum diberlakukannya norma-norma hukum terkait maupun yang telah disepakati setelah pemberlakuannya. ${ }^{8}$ Selain itu ketika memasuki masa pandemi Covid-19, banyak debitur yang mengalami permasalahan untuk memenuhi prestasi dari kontrak yang telah disepakati dan hal tersebut terjadi sebelum diberlakukannya

$5 \quad$ Seringkali terjadi miskonsepsi berbagai kalangan dalam memandang istilah Keputusan Presiden dan Peraturan Presiden. Hal ini dikarenakan meskipun masih dapat dikeluarkan oleh seorang pemegang kekuasaan eksekutif, Undang-Undang Nomor 12 Tahun 2011 tentang Pembentukan Peraturan Perundang-Undangan tidak menggunakan istilah Keputusan Presiden melainkan Peraturan Presiden. Hal ini semakin menegaskan perluasan kewenangan kekuasaan eksekutif dalam membentuk peraturan perundang-undangan karena sifat dari Peraturan Presiden dapat mengatur perihal yang abstrak dan umum sedangkan Keputusan Presiden secara prinsipnya hanya dapat mengatur perihal yang bersifat individual dan konkret. Lihat: Ahmad Husen, "Eksistensi Peraturan Presiden Dalam Sistem Peraturan PerundangUndangan", Lex Scientia Law Review, Vol.3 No.1, Fakultas Hukum Universitas Negeri Semarang, 2019, hlm. 76.

$6 \quad$ Hukum publik merupakan hukum normatif yang mengatur kepentingan umum dan dalam beberapa keadaan tertentu dapat juga ditujukan untuk membatasi hukum privat dengan tidak bermaksud untuk meniadakan sifatnya secara utuh. Lihat: E. Utrecht dan M. Saleh Djindang, Pengantar dalam Hukum Indonesia, (Jakarta: Penerbit dan Balai Buku Ichtiar, 1982), hlm. 32 dalam Rahayu Prasetianingsih, "Konstusionalisasi Hukum Privat: Beberapa Pandangan yang Bekembang dalam Pengkajian Ilmu Hukum", Padjajaran Jurnal Ilmu Hukum, Vol.1 No.2, Fakultas Hukum Universitas Padjajaran, 2014, hlm. 372.

$7 \quad$ Pasal 1 ayat (2) Undang-Undang Nomor 6 Tahun 2018 tentang Kekarantinaan Kesehatan.

8 Dalam hukum kontrak dikenal terdapat tiga tahapan dalam pembuatan kontrak yaitu meliputi tahap pra-kontraktual, tahap kontraktual, dan post-kontraktual. Tahap post-kontraktual sendiri dapat juga disebut sebagai tahap pelaksanaan kontrak atau rentang waktu setelah penandatanganan kontrak dilakukan. Lihat: Cicik Nur Hayati, "Karakteristik Head of Agreement Menurut Hukum Kontrak Indonesia", The Juris-Diction Journal, Vol.2 No.3, Fakultas Hukum Universitas Airlangga, 2019, hlm. 857. 
PP 21/2020, Keppres 11/2020, dan Keppres 12/2020 tersebut.

Oleh karena itu memperhatikan keadaan pandemi Covid-19 yang masih bergerak statistiknya secara fluktuatif dan belum terdapat kepastian terhadap berakhirnya keadaan tersebut, perlu dilakukan sebuah penelaahan terhadap hubungan akibat hukum dalam hukum kontrak terkait terjadinya pandemi Covid 19 beserta diberlakukannya PP 21/2020, Keppres 11/2020, dan Keppres 12/2020 dengan interpretasi hukum terhadap klausula keadaan memaksa itu sendiri. Oleh karena itu tulisan ini akan menguraikan secara lebih lanjut perihal hal tersebut. Berdasarkan pendahuluan diatas, maka rumusan permasalahan dalam penelitian ini adalah meliputi:

(1) Bagaimana perspektif hukum kontrak memandang status kedaruratan kesehatan masyarakat sebagai kategori keadaan memaksa?

(2) Bagaimana perlindungan hukum kepada para pihak akibat diberlakukannya status kedaruratan kesehatan masyarakat?

\section{B. Metode Penelitian}

Penelitian ini merupakan penelitian hukum yang dilakukan secara normatif. Penelitian hukum normatif merupakan bentuk penelitian hukum yang menggunakan kajian komprehensif terhadap asas dan prinsip hukum, doktrin hukum dan norma hukum positif dalam menyusun penelitian tersebut. ${ }^{9}$ Penelitian ini menggunakan metode pendekatan peraturan perundang-undangan dan metode pendekatan konseptual. Pendekatan peraturan perundang- undangan merupakan upaya penelaahan terhadap sebuah tata peraturan perundangundangan yang berlaku dalam menyikapi sebuah permasalahan hukum sedangkan pendekatan konseptual lebih menggunakan kajian doktrinal hukum dalam mengargumentasikan pendapat perihal permasalahan hukum itu sendiri. ${ }^{10}$

Teknik pengumpulan bahan hukum yang digunakan adalah melalui studi kepustakaan atau dapat pula diartikan sebagai penelusuran terhadap literatur ilmiah yang berkenaan dengan pokok permasalahan penelitian. ${ }^{11}$ Bahan hukum yang digunakan dalam penelitian ini terdiri dari bahan hukum primer yang meliputi Kitab Undang-Undang Hukum Perdata dan peraturan perundang-undangan yang memiliki relevansi dan bahan hukum sekunder yang meliputi doktrin hukum yang telah berkembang secara umum. Analisis bahan hukum yang digunakan adalah analisis dengan metode pendekatan kualitatif. Selain itu penelitian ini juga menggunakan metode deduktif sebagai teknik pengambilan kesimpulan dalam penelitian ini. Metode deduktif merupakan metode penarikan kesimpulan dengan menguraikan hal yang bersifat umum dan diakhiri dengan hal yang bersifat lebih khusus.

\section{Pembahasan}

1. Perspektif Hukum Kontrak Terkait Keadaan Kedaruratan Kesehatan Masyarakat Sebagai Alasan Penerapan Klausula Keadaan Memaksa

Pemberlakuan Keppres 11/2020 dan Keppres 12/2020 berimplikasi bahwa keadaan kedaruratan kesehatan masyarakat bersifat

9 Dalam teori hukum dijelaskan bahwasanya penelitian hukum secara umum dapat dilakukan secara normatif dan empiris. Penelitian yang dilakukan dengan metode empiris pada umumnya menggunakan data hukum yang didapatkan dari hasil penelitian lapangan baik yang berupa hasil wawancara, kuisioner maupun survei secara berjenjang. Lihat: Abdulkadir Muhammad, Hukum dan Penelitian Hukum, (Bandung: Citra Aditya Bakti, 2004), hlm. 52.

10 Peter Mahmud Marzuki, Penelitian Hukum Edisi Revisi, (Jakarta: Kencana, 2012), hlm. 36.

11 Sugiyono, Memahami Penelitian Kualitatif, (Bandung: Alfabeta, 2012), hlm. 291. 
mengikat secara umum. Hal tersebut secara signifikan mempengaruhi berjalannya sebuah prestasi dalam sebuah kontrak. Dimana jenis kontrak yang paling terdampak oleh pemberlakuan PP 21/2020, Keppres 11/2020, dan Keppres 12/2020 adalah kontrak yang mengatur pelaksanaan prestasi yang diwujudkan melalui kegiatan melakukan sesuatu atau kegiatan memberikan sesuatu yang dilakukan secara langsung dan berkelanjutan seperti pada kegiatan pemborongan, kegiatan ekspedisi, atau kegiatan sejenis lainnya.

Pelaksanaan prestasi dalam kontrak yang berhubungan dengan hal ikhwal kegiatan diatas semakin terdampak dengan pemberlakuan PP 21/2020. Dimana Pasal 4 ayat (1) PP 21/2020 menerangkan bahwa pembatasan sosial berskala besar setidaknya meliputi peliburan sekolah dan tempat kerja, pembatasan kegiatan keagamaan, dan/atau pembatasan kegiatan di tempat atau fasilitas umum. Merujuk pada pembatasan kegiatan di tempat atau fasilitas umum tersebut, terdapat implikasi bahwa pelaksanaan kontrak yang berkarakteristik sebagaimana dimaksudkan diatas dimungkinkan untuk tidak dapat berjalan sebagaimana yang telah disepakati oleh para pihak sebelumnya.

Dengan terbukanya kemungkinan tersebut maka prestasi yang dibebankan kepada pihak kreditur akan turut terdampak oleh pemberlakuan Keppres 11/2020 dan Keppres 12/2020 bahkan secara khusus terkait pada PP 21/2020. Sehingga tidak dapat dipungkiri dengan terdampaknya prestasi yang seharusnya dipenuhi oleh pihak kreditur maka wanprestasi dapat terjadi diantara para pihak. Merujuk pada substansi KUHPer secara komprehensif maka dapat dikemukakan bahwa wanprestasi sendiri dapat terdiri dari dua jenis klasifikasi.
Klasifikasi wanprestasi yang pertama adalah wanprestasi yang dikehendaki oleh pihak kreditur. Mengenai klasifikasi wanprestasi ini setidaknya harus memenuhi dua unsur di dalamnya. Unsur pertama adalah unsur itikad buruk. Unsur itikad buruk yang dimaksudkan adalah apabila pihak kreditur secara sadar bahwa tindakannya dalam pelaksanaan prestasi yang dibebankan kepadanya berpotensi merugikan kepentingan debitur. Dimana meskipun pihak kreditur mempunyai kesadaran tersebut, pihak kreditur tidak melakukan upaya preventif terhadap penerbitan kerugian kepada pihak debitur akibat dari tindakannya.

Selain unsur itikad buruk, unsur yang kedua adalah terdapatnya unsur penipuan yang terjadi dalam kurun waktu pelaksanaan kontrak. Hal ini untuk membedakan konstruksi unsur penipuan yang dimaksudkan oleh Pasal 1328 KUHPer. Ketentuan Pasal 1328 KUHPer menerangkan bahwa penipuan merupakan alasan untuk membatalkan persetujuan dimana penipuan tersebut menjadi dasar untuk menegakkan persetujuan terkait. ${ }^{12}$

Ketentuan Pasal 1328 KUHPer tersebut dapat dipahami bahwa penipuan dapat menjadi alasan untuk dimintakannya pembatalan sebuah persetujuan diantara para pihak apabila unsur penipuan tersebut telah terang dilakukan pada saat fase kontraktual. Hal ini sekaligus untuk menegaskan bahwa apabila unsur penipuan tersebut terjadi pada kurun pelaksanaan prestasi dalam kontrak tersebut maka tidaklah tepat untuk mengacu kepada ketentuan Pasal 1328 KUHPer. Dimana ketentuan Pasal 1247 KUHPer mengemukakan bahwa penggantian biaya, kerugian, dan bunga sebagai bentuk kerugian yang ditanggung pihak kreditur akibat unsur penipuan yang dilakukan pihak debitur tetap

12 Pasal 1328 Kitab Undang-Undang Hukum Perdata. 
dapat dimintakan pertanggungjawabannya oleh pihak kreditur kepada pihak debitur tanpa mengakibatkan batalnya kontrak yang telah disepakati. ${ }^{13}$

Klasifikasi wanprestasi yang kedua adalah wanprestasi yang tidak dikehendaki. Dalam klasifikasi ini, wanprestasi dapat disebabkan oleh dua alasan. Alasan yang pertama adalah wanprestasi yang disebabkan oleh kelalaian. Wanprestasi yang disebabkan oleh kelalaian diterangkan secara tegas di dalam ketentuan Pasal 1234 KUHPer namun unsur kelalaian tersebut harus dibuktikan secara terang diantara para pihak. ${ }^{14}$ Alasan yang kedua adalah wanprestasi yang disebabkan oleh unsur sebab memaksa. Wanprestasi yang disebabkan oleh sebab memaksa tersebut dapat mengacu kepada ketentuan Pasal 1245 KUHPer yang menerangkan bahwa wanprestasi yang terjadi karena sebab memaksa tidak menerbitkan penggantian biaya, kerugian, dan bunga yang seharusnya dibebankan kepada pihak kreditur. ${ }^{15}$

Namun perlu juga untuk dipahami bahwa unsur sebab memaksa atau keadaan memaksa harus dipahami dalam sebuah kerangka teori yang utuh. Pada prinsipnya, sebuah keadaan dapat terkategori sebagai keadaan memaksa apabila:

\section{a. Keadaan Tersebut Tidak Diduga Akan Terjadi Sebelumnya}

Keadaan tidak terduga tersebut pada prinsipnya merupakan suatu keadaan yang sebelumnya terjadi dalam kurun pelaksanaan kontrak tersebut tidak dipersangkakan baik oleh pihak debitur dan pihak kreditur. Persangkaan yang dimaksudkan adalah dimana keadaan tersebut pada mulanya tidak melekat atau dilekatkan kepada salah satu pihak atau para pihak dalam kontrak secara keseluruhan. Dimana yang dimaksudkan keadaan yang tidak terduga mulanya tidak melekat pada salah satu pihak atau para pihak secara keseluruhan adalah keadaan yang tidak terduga tersebut kemudian mengakibatkan para pihak mengalami permasalahan serupa apabila dikondisikan menjadi pihak kreditur sedangkan keadaan yang tidak terduga yang dilekatkan kepada para pihak merupakan keadaan yang tidak terduga tersebut terjadi karena adanya perintah Undang-Undang atau putusan pengadilan berkekuatan hukum tetap yang hanya mengikat salah satu pihak dalam kontrak tersebut.

\section{b. Sifat dari Keadaan Tersebut Secara Alamiah Dapat Menangguhkan Terlaksananya Prestasi Dalam Kontrak Terkait}

Sifat alamiah yang dimaksudkan adalah dimana keadaan memaksa tersebut meskipun tidak dilakukan melalui paksaan oleh norma hukum akan tetap dapat menyebabkan prestasi tersebut tertangguh bahkan tidak dapat dijalankan secara penuh. Meskipun sebagaimana disebutkan diatas bahwa keadaan memaksa dapat terjadi karena adanya perintah UndangUndang atau putusan pengadilan berkekuatan hukum tetap, tanpa diberlakukannya secara paksa perintah Undang-Undang atau putusan pengadilan berkekuatan hukum tetap maka secara alamiah keadaan memaksa tersebut secara langsung telah menyebabkan tertangguhnya atau tidak dapat dijalankannya prestasi tersebut oleh pihak kreditur secara utuh.

\footnotetext{
Pasal 1248 Kitab Undang-Undang Hukum Perdata.

Pasal 1243 Kitab Undang-Undang Hukum Perdata.

Pasal 1245 Kitab Undang-Undang Hukum Perdata.
} 


\section{c. Tidak Terdapatnya Itikad Buruk Baik oleh Debitur maupun Kreditur}

Itikad buruk yang dimaksudkan dapat dimaknai bahwa sepanjang terjadinya keadaan memaksa tersebut tidaklah terdapat itikad buruk pihak debitur atau pihak kreditur melalui penyelundupan hukum. Hal ini sekaligus untuk menegaskan bahwa dimungkinkannya penyelundupan hukum oleh pihak debitur atau pihak kreditur hingga tekanan kepada pihak kreditur mengenai pelaksanaan prestasi yang seharusnya dipenuhi oleh pihak kreditur. Apabila diketemukan itikad buruk oleh salah satu pihak maka tidaklah dapat keadaan memaksa tersebut dijadikan dasar bertindak oleh para pihak dalam kontrak terkait.

\section{d. Kelalaian dan Gagal Terpenuhinya Prestasi oleh Pihak Kreditur Terjadi Setelah Terjadinya Keadaan yang Bersifat Memaksa}

Hal ini dimaknai sepanjang kelalaian tersebut terjadi pada saat keadaan memaksa maka dapat disebutkan sebagai keadaan memaksa namun apabila kelalaian tersebut terjadi atau potensi kelalaian atau gagal terpenuhinya prestasi oleh pihak kreditur sebelum terjadinya keadaan memaksa tidak dapat disebut sebagai dasar penangguhan prestasi oleh pihak kreditur dengan dalil keadaan memaksa. Hal ini sekaligus untuk menegaskan bahwa terdapat perbedaan mendasar mengenai gagal terpenuhinya prestasi oleh pihak kreditur baik dikarenakan keadaan memaksa dan sebelum keadaan memaksa. Dimana merujuk pada ketentuan Pasal 1245 KUHPer, sepanjang gagal terpenuhinya prestasi oleh pihak kreditur terjadi sejak belum terjadinya keadaan memaksa maka dapat dimintakan pertanggungjawabannya oleh pihak debitur sepanjang terjadi pada kurun waktu terjadinya sebelum keadaan memaksa.

Sehingga berdasarkan penjelasan keempat prinsip di atas, keadaan kedaruratan kesehatan masyarakat dapat diklasifikasikan sebagai keadaan memaksa apabila memenuhi keseluruhan dari prinsip-prinsip yang disebutkan diatas. Berikut akan diuraikan lebih lanjut mengenai hubungan keseluruh prinsip tersebut dengan keadaan kedaruratan kesehatan masyarakat yang dalam hal ini adalah pandemi Covid-19. Pertama, seperti diketahui bahwa untuk dikategorikan sebagai keadaan memaksa maka sebuah keadaan tersebut merupakan keadaan yang tidak diduga sebelumnya. Pandemi Covid-19 merupakan salah satu bencana non alam yang tidak dapat diprediksikan sebelumnya. ${ }^{16}$ Sehingga apabila sebuah kontrak disepakati sebelum penetapan Keppres 11/2020 dan Keppres 12/2020 maka keadaan kedaruratan kesehatan masyarakat dapat dijadikan sebagai dalil dari keadaan memaksa namun apabila kontrak disepakati sebelum penetapan Keppres 11/2020 dan Keppres $12 / 2020$ maka keadaan kedaruratan kesehatan masyarakat tidak dapat serta merta digolongkan sebagai keadaan memaksa karena terdapat terdapat pengetahuan dari para pihak mengenai hal tersebut dan konsekuensinya apabila membentuk sebuah kontrak terkait aktivitas yang terdampak oleh pandemi Covid-19.

Kedua, sifat alamiah dari keadaan memaksa tersebut haruslah secara alamiah berdampak kepada penangguhan dari pelaksanaan sebuah

16 Secara yuridis, bencana dikategorikan menjadi tiga jenis yaitu bencana alam, bencana non alam, dan bencana sosial. Salah satu jenis bencana yang sulit untuk diprekdisi untuk terjadi adalah bencana non alam. Bencana nonalam adalah bencana yang diakibatkan oleh peristiwa atau rangkaian peristiwa nonalam yang antara lain berupa gagal teknologi, gagal modernisasi, epidemi, dan wabah penyakit. Lihat ketentuan Pasal 1 ayat (2), ayat (3), dan ayat (4) UndangUndang Nomor 24 Tahun 2007 tentang Penanggulangan Bencana. 
prestasi. Dalam hal ini, keadaan kedaruratan kesehatan masyarakat atau pandemi Covid-19 merupakan keadaan yang secara alamiah akan menangguhkan pelaksanaan sebuah prestasi pada sebuah kontrak. Namun perlu diperhatikan bahwa harus dipenuhi juga prinsip kewajaran sebelum menetapkan bahwa penyebab dari tidak terlaksananya prestasi tersebut adalah karena sebab pandemi Covid-19 sehinggatidak seluruh bentuk pelaksanaan dari prestasi pada kontrak langsung dapat digolongkan sebagai dalil keadaan memaksa. Dimana apabila prestasi dalam sebuah kontrak tidak terkait dengan aktivitas yang terdampak pandemi Covid-19 secara signifikan dan berbentuk prestasi untuk tidak berbuat sesuatu maka meskipun dilaksanakan pada keadaan pandemi Covid-19 maka debitur pada kontrak dengan karakteristik tersebut tidak dapat mendalil pandemi Covid-19 sebagai keadaan memaksa baginya untuk melaksanakan prestasi tersebut.

Ketiga, tidak terdapatnya itikad buruk baik pada pihak debitur dan pihak kreditur. Meskipun sebagaimana yang diterangkan diatas bahwa keadaan kedaruratan kesehatan masyarakat merupakan sebuah keadaan yang tidak dapat terduga sebelumnya, pendalilan keadaan memaksa harus memperhatikan probabilitas dari itikad yang dimiliki oleh para pihak. Dimana apabila keadaan kedaruratan kesehatan masyarakat dijadikan sebagai alasan untuk menghindari atau untuk tidak menjalankan prestasi tersebut secara kesadaran penuh maka keadaan pandemi Covid-19 tidak dapat menjadi dalil baginya meskipun prestasi dalam kontrak tersebut berkenaan dengan aktivitas yang berdampak secara siginifikan karena pandemi Covid-19. Selain itu, hal ini juga berlaku kepada pihak kreditur. Dimana apabila pihak kreditur membebankan tambahan kewajiban dalam pemenuhan prestasi yang tidak sewajarnya kepada pihak debitur karena penerapan klausula keadaan memaksa maka dalil untuk menegaskan keadaan kedaruratan kesehatan masyarakat sebagai keadaan memaksa patutlah untuk dikesampingkan.

Keempat, apabila terdapat kegagalan atau kelalaian dalam memenuhi prestasi oleh pihak debitur setelah terjadinya keadaan yang bersifat memaksa tersebut maka keadaan kedaruratan kesehatan masyarakat dapat dijadikan sebagai dalil keadaan memaksa. Tetapi apabila kegagalan atau kelalaian dalam memenuhi prestasi terjadi sebelum terjadinya keadaan yang bersifat memaksa tersebut maka dalil keadaan memaksa tidak dapat diterapkan oleh para pihak. Sehingga berkenaan dengan pandemi Covid-19, apabila telah terjadi kegagalan atau kelalaian dalam memenuhi prestasi yang dilakukan oleh debitur dan telah diikuti oleh somasi dari pihak kreditur maka debitur tidak dapat menangguhkan kontrak tersebut atas dalil keadaan memaksa. Namun apabila debitur tersebut dapat membuktikan bahwa terdapat signifikansi dari permulaan terjadinya pandemi Covid-19 yang melatarbelakangi diberlakukannya Keppres $11 / 2020$ dan Keppres 12/2020 maka hal tersebut patut untuk dipertimbangkan secara seksama oleh pihak kreditur.

Yang perlu digarisbawahi juga adalah bahwa apabila Keppres 11/2020 dan Keppres 12/2020 telah dinyatakan tidak mengikat keberlakuannya lagi dikemudian hari maka penangguhan pelaksanaan prestasi dalam sebuah kontrak yang aktivitasnya terdampak signifikan karena pandemi Covid-19 pun berakhir. Sehingga dalil keadaan memaksa tidak dapat lagi digunakan oleh pihak debitur untuk memperpanjang masa penangguhan pelaksanaan prestasinya apabila pelaksanaan prestasi tersebut berada pada 
tingkat kewajaran dan bersifat ideal.

\section{Perlindungan Hukum Bagi Para Pihak Atas Pemberlakuan Keadaan Kedaruratan Kesehatan Masyarakat Sebagai Klausula Keadaan Memaksa}

Dalam pembahasan sebelumnya telah diuraikan mengenai pemahaman disertai dengan batasan-batasan tertentu dalam menerapkan dalil keadaan kedaruratan kesehatan masyarakat sebagai keadaan memaksa. Namun setelah memahami hal tersebut perlu juga untuk dipahami bahwa terdapat pembedaan tindakan terhadap penerapan dalil kedaruratan kesehatan masyarakat sebagai klausula keadaan memaksa dalam sebuah kontrak. Pembedaan tersebut didasarkan pada pemuatan klausula keadaan memaksa dalam suatu kontrak.

Perbedaan yang dimaksud adalah kontrak yang memuat klausula keadaan memaksa dan kontrak yang tidak memuat klausula keadaan memaksa. Dalam melakukan perlindungan bagi para pihak menurut dua jenis kontrak tersebut maka akan diuraikan secara lanjut sebagai berikut.

\section{a. Perlindungan Hukum bagi Para Pihak dalam Kontrak yang Memuat Klausula Keadaan Memaksa}

Sebuah kontrak dapat dinyatakan memuat klausula keadaan memaksa apabila dinyatakan terang di dalam kontrak tersebut. Klausula keadaan memaksa yang dimaksudkan tersebut turut mencakup juga keadaan seperti keadaan kesehatan kedaruratan kesehatan masyarakat. Dalam hal ini, pemuatan klausula keadaan memaksa dalam kontrak terkait dapat digolongkan ke dalam dua tipologi. Tipologi yang pertama adalah klausula keadaan memaksa yang mengatur mengenai penyelesaian sengketa diantara para pihak apabila keadaan memaksa terjadi diantara para pihak. Dalam tipologi pertama ini maka penyelesaian sengketa akan merujuk kepada klausula keadaan memaksa yang disepakati oleh para pihak sebelumnya meskipun tidak tertutup kemungkinan apabila disepakati lain oleh para pihak untuk memilih forum penyelesaian sengketa di luar klausula keadaan memaksa yang disepakati sebelumnya.

Tipologi yang kedua adalah klausula keadaan memaksa yang diatur oleh para pihak namun tidak menjelaskan mengenai jalur penyelesaian sengketa yang disepakati oleh para pihak untuk ditempuh apabila klausula tersebut diberlakukan oleh para pihak. Selain itu terdapat pula klausula keadaan memaksa yang diatur secara tidak jelas yaitu dimana klausula keadaan memaksa yang diatur tidak mengatur dengan merinci mengenai kategorisasi keadaan memaksa. Sehingga tipologi kedua ini tidaklah dapat dipersamakan dengan tipologi pertama mengenai jalur penyelesaian sengketa dan pola perlindungan hukumnya bagi para pihak baik pihak debitur atau pihak kreditur.

Dalam melakukan perlindungan hukum bagi para pihak yang menggunakan tipologi kedua maka dapat dilakukan melalui dua solusi yaitu melalui penafsiran yang bersifat ekstensifikasi oleh para pihak. Namun apabila tidak diketemukan kesepakatan diantara para pihak mengenai penafsiran klausula keadaan memaksa tersebut maka dapat dilakukan penyelesaian sengketa melalui mediasi ataupun jalur litigasi. Perlu untuk digarisbawahi bahwa idealnya jalur penyelesaian sengketa non litigasi, hal ini ditujukan agar terciptanya pendamaian diantara para pihak dan dapat mengakomodasi kepentingan seluruh pihak dan tidak hanya untuk mencapai kepastian hukum semata melainkan juga dapat menyelesaikan sengketa melalui jalur yang akomodatif. 


\section{b. Perlindungan Hukum bagi Para Pihak dalam Kontrak yang Tidak Memuat Klausula Keadaan Memaksa}

Dalam hal kontrak yang tidak memuat klausula keadaan memaksa secara terang atau dinyatakan secara diam-diam maka perlindungan hukum bagi para pihak baik pihak debitur atau pihak kreditur menjadi hal yang penting untuk dibahas secara berimbang. Sebuah kontrak yang tidak memuat klausula keadaan memaksa secara terang pada dasarnya dapat diselesaikan melalui kesepakatan para pihak. Namun yang menjadi perbedaan dengan pemuatan klausula keadaan memaksa secara terang adalah dalam proses menafsirkan kehendak para pihak terkait keadaan memaksa menjadi tidak sama.

Karenanya tidak dipungkiri bahwa penangguhan pelaksanaan sebuah prestasi karena sebab diterapkannya dalil keadaan memaksa dalam sebuah kontrak yang tidak memuat klausula keadaan memaksa menjadi sebuah permasalahan hukum diantara para pihak. Oleh karena itu terdapat dua langkah yang dapat ditempuh untuk mencapai nilai kepastian hukum pada tipologi kontrak tersebut dapat tercapai dengan baik. Dua langkah tersebut adalah dengan melakukan pembaharuan kontrak atau melakukan pemutusan terhadap kontrak tersebut.

Pertama, pembaharuan kontrak merupakan upaya dari para pihak untuk melakukan perubahan terhadap substansi dari kontrak terkait. Perubahan ini dapat mencakup dari keseluruhan kontrak namun dapat pula dilakukan hanya secara sebagian. Pembaharuan kontrak yang dilakukan apabila dikaitkan dengan diterapkannya dalil keadaan memaksa akan memberi ruang bagi para pihak untuk meninjau ulang substansi dari kontrak tersebut yang memiliki kemungkinan untuk tidak dapat dipenuhi selama terjadinya keadaan memaksa tersebut.

Kedua, dapat pula dilakukan pemutusan kontrak apabila tidak terdapat kepastian secara berkelanjutan dengan diterapkannya dalil keadaan memaksa. Pasal 1381 KUHPer menerangkan bahwa sebuah perikatan dapat hapus dikarenakan sebab-sebab sebagai berikut:

a. karena pembayaran;

b. karena penawaran pembayaran tunai, diikuti dengan penyimpanan atau penitipan;

c. karena pembaruan utang;

d. karena perjumpaan utang atau kompensasi;

e. karena percampuran utang;

f. karena pembebasan utang;

g. karena musnahnya barang yang terutang;

h. karena kebatalan atau pembatalan;

i. karena berlakunya syarat pembatalan yang diatur dalam Bab I buku ini; dan

j. karena lewat waktu, yang akan diatur dalam suatu bab sendiri.

Sebagaimana yang diterangkan pada ketentuan Pasal 1381 KUHPer diatas bahwa salah satu hal yang dapat menjadi alasan putusnya sebuah perikatan adalah adalah musnahnya barang yang terutang. Perlu digarisbawahi bahwa frasa musnah pada ketentuan tersebut tidak serta-merta diartikan sebagai hilangnya atau tidak diketemukannya secara keseluruhan barang yang terutang atau objek dari kontrak. Hal ini dikarenakan frasa musnah dapat pula ditafsirkan dimana barang yang terutang atau objek dari kontrak ketika tidak dijalankan prestasinya maka akan kehilangan nilai ekonomisnya. Selain itu juga perlu dipahami selain karena sebab-sebab yang ditentukan pada ketentuan Pasal 1381 KUHPer, para pihak dapat memutuskan sebuah kontrak atas dasar kesepakatan mereka dengan memperhatikan tidak merugikan satu sama lain atau disepakati 
ditanggungnya kerugian secara berimbang.

Salah satu asas hukum yang harus diterapkan pada pelaksanaan prestasi pada sebuah kontrak adalah asas perlindungan hukum. Hal ini ditujukan agar masing-masing pihak dalam kontrak mempunyai kedudukan yang sama di depan hukum. Selain itu tidak dimungkinkannya bagi salah satu pihak untuk melakukan kecurangan atau menimbulkan kerugian kepada pihak lainnya.

Dalampermasalahan pemberlakuanklausula keadaan memaksa akibat terjadinya keadaan kedaruratan kesehatan masyarakat maka pihak yang secara kepentingannya dirugikan adalah pihak kreditur. Hal ini dikarenakan pihak debitur tidak akan secara maksimal atau bahkan tidak dapat memenuhi prestasinya secara keseluruhan. Apabila sebuah klausula keadaan memaksa diterapkan dalam rentang waktu yang lama atau tidak dapat diprediksikan akhirnya secara pasti maka kerugian yang akan timbul dan ditanggung oleh pihak kreditur akan semakin besar. Oleh karena itu diperlukan langkah konkret dari para pihak untuk dapat menentukan kesepakatannya mengenai klausula keadaan memaksa tersebut. Selain kedua langkah tersebut dapat pula dilakukan langkah-langkah lain seperti melakukan pengajuan penyelesaian sengketa baik melalui jalur litigasi maupun jalur non litigasi. Jalur non litigasi dapat dilakukan dengan mediasi dan alternatif penyelesaian sengketa sebagaimana yang dilaksanakan dalam tipologi kontrak yang memuat klausula keadaan memaksa secara terang.

\section{Penutup}

Sebuah norma hukum hakikatnya dibentuk untuk melindungi rakyat dan menjamin bahwa hak dan kewajiban konstitutionalnya dapat terpenuhi dengan baik. Keadaan mendesak yang terjadi dalam sebuah negara merupakan tanggung jawab pemerintah yang berdaulat untuk menanggulanginya. Namun meskipun demikian pembentukan sebuah norma hukum pada keadaan mendesak yang dibentuk oleh pemerintah seharusnya tidak hanya memperhatikan nilai kepastian hukum melainkan harus juga memperhatikan nilai keadilan dan nilai kemanfaatan hukum secara berimbang.

Berdasarkan pembahasan yang telah diterangkan sebelumnya maka penelitian menghasilkan beberapa kesimpulan yang akan diuraikan sebagai berikut. Pertama, status kedaruratan kesehatan masyarakat dapat dikategorikan sebagai keadaan memaksa apabila memenuhi keempat syarat yaitu apabila keadaan tersebut tidak diduga akan terjadi sebelumnya, sifat dari keadaan tersebut secara alamiah dapat menangguhkan terlaksananya prestasi dalam kontrak terkait, tidak terdapatnya itikad buruk baik oleh debitur maupun kreditur, dan, kelalaian atau gagal terpenuhinya prestasi oleh debitur terjadi setelah terjadinya keadaan yang bersifat memaksa. Keseluruhan syarat tersebut harus dipenuhi secara akumulatif dan apabila salah satu syarat tersebut tidak terpenuhi maka dalil keadaan memaksa terkait kedaruratan kesehatan masyarakat tidak dapat diterapkan. Selain itu apabila dikemudian hari Keppres 11/2020 dinyatakan tidak mengikat keberlakuannya maka dalil keadaan memaksa terkait kedaruratan kesehatan masyarakat tersebut akan gugur demi hukum. Kedua, para pihak untuk mencapai kepastian hukum dan perlindungan hukum akibat diterapkannya klausula keadaan memaksa dapat melakukan penafsiran terhadap klausula keadaan memaksa, pembaharuan kontrak secara keseluruhan atau sebagian maupun melakukan pemutusan kontrak. 


\section{Daftar Pustaka}

\section{A. Buku}

Marzuki, Peter Mahmud, Penelitian Hukum Edisi Revisi (Jakarta: Kencana, 2012).

Muhammad, Abdulkadir, Hukum dan Penelitian Hukum, (Bandung: Citra Aditya Bakti, 2004.

Cicero, Marcus Tullius, De Re Publica, De Legibus, Cato Maior de Senectute, Laelius de Amicitia, (Oxford: Oxford University Press, 2006).

Sugiyono, Memahami Penelitian Kualitatif (Bandung: Alfabeta, 2012).

Utrecht, E. dan Saleh Djindang, M., Pengantar dalam Hukum Indonesia, (Jakarta: Penerbit dan Balai Buku Ichtiar, 1982)

\section{B. Makalah/Artikel/Prosiding/Hasil Penelitian}

E. Arde-Acquah, Phoebe, "Salus Populi Suprema Lex Esto: Balancing Civil Liberties and Public Health Interventions in Modern Vaccination Policy, Washington University Jurisprudence Review (2015)

Husen, Ahmad, "Eksistensi Peraturan Presiden Dalam Sistem Peraturan Perundang-undangan", Lex Scientia Law Review (2019).

Nur Hayati, Cicik, "Karakteristik Head Agreement Menurut Hukum Kontrak Indonesia", The Juris-Diction Journal (2019).

Prasetianingsih, Rahayu, "Konstusionalisasi Hukum Privat: Beberapa Pandangan yang Bekembang dalam Pengkajian IImu Hukum", Padjajaran Jurnal IImu Hukum (2014).

\section{Peraturan Perundang-Undangan}

Undang-Undang Dasar Negara Republik Indonesia Tahun 1945

Kitab Undang-Undang Hukum Perdata

Undang-Undang Nomor 1 Tahun 1974 tentang Perkawinan

Undang-Undang Nomor 24 Tahun 2007 tentang Penanggulangan Bencana.

Undang-Undang Nomor 6 Tahun 2018 tentang Kekarantinaan Kesehatan

Peraturan Pemerintah Nomor 21 Tahun 2020 tentang Pembatasan Sosial Berksala Besar Dalam

Rangka Percepatan Penanganan Corona Virus Disease 2019 (Covid-19)

Keputusan Presiden Nomor 11 Tahun 2020 tentang Penetapan Kedaruratan Kesehatan Masyarakat Corona Virus Disease 2019 (Covid-19)

Keputusan Presiden Nomor 12 Tahun 2020 tentang Penetapan Bencana Nonalam Penyebaran Corona Virus Disease (Covid-19) Sebagai Bencana Nasional 


\section{BIODATA PENULIS}

Kristianus Jimy Pratama, S.H. menyelesaikan pendidikan pada S1 IImu Hukum Fakultas Hukum Universitas Sriwijaya. Saat ini penulis merupakan mahasiswa aktif pada Program Studi Magister Hukum Bisnis dan Kenegaraan Fakultas Hukum Universitas Gadjah Mada. Penulis memiliki artikel penelitian baik yang dikerjakan secara mandiri dan kolaborasi yang diantaranya adalah yang berjudul "Study of Development of Indonesia'Remuneration Law System" (2019) dan "The Indonesian Legal Paradigm Concept About Tort Law (Analyse Toward Court Decision Number 42/PDT.G/2014/PN.BYL" (2019) yang dipublikasikan pada Social Science Research Network (SSRN) by Elsevier dan sebuah penulisan hukum skripsi yang berjudul "Akibat Pemanfaatan Mata Uang Virtual Pada Layanan Overstock.com Oleh Konsumen Indonesia" yang dipertahankan substansinya di Fakultas Hukum Universitas Sriwijaya. Fokus penelitian penulis adalah bidang hukum bisnis yang meliputi hukum kontrak, hukum perdata internasional, dan hukum ketenagakerjaan. Penulis dapat dihubungi melalui email: kristianusjimy@ mail.ugm.ac.id. 